\title{
Production and Purification of the Endoglucanase Enzyme from Local Isolate Aspergillus fumigatus HBF356
}

\author{
Ali Tahreer Abdulmajeed Abdulmajeed ${ }^{1}$ (D) , Selmihan Şahin ${ }^{1}$ (D) , Ismail Ozmen 1,* ${ }^{D}$ \\ 1 Faculty of Arts and Sciences, Department of Chemistry, Suleyman Demirel University, Cunur, Isparta 32260, Turkey; \\ alialazzawi9000@gmail.com (A.T.A.A.); selmihansahin@sdu.edu.tr (S.S.); ismailozmen@sdu.edu.tr (I.O.); \\ * Correspondence: ismailozmen@ @sdu.edu.tr (I.O.);
}

Received: 25.05.2021; Revised: 30.07.2021; Accepted: 2.08.2021; Published: 15.08.2021

\begin{abstract}
In this study, endoglucanase (EG) from local isolate Aspergillus fumigatus HBF356 was produced and purified using ammonium sulfate precipitation, gel filtration chromatography, and ionexchange chromatography. The molecular weight of the pure EG was determined as $95 \mathrm{kDa}$. The optimum $\mathrm{pH}$ of the purified EG was determined as 4.0 and the optimum temperature as $60^{\circ} \mathrm{C}$. It has been observed that the enzyme had a very high thermostability and preserved $75.8 \%$ of its activity after 240 hours of incubation at $50{ }^{\circ} \mathrm{C}$. At the same time, the effect of veterinary drugs (gentamicin sulfate and enrofloxacin) on the activity of the EG was investigated. The activity of EG was inhibited by gentamicin sulfate while that was activated with enrofloxacin. The results of this study can give information about the potential of EG from Aspergillus fumigatus HBF356 using as a feed additive and its interaction with animal drugs.
\end{abstract}

Keywords: CMCase; purification; characterization; metal salts; surfactants; kinetic study.

(C) 2021 by the authors. This article is an open-access article distributed under the terms and conditions of the Creative Commons Attribution (CC BY) license (https://creativecommons.org/licenses/by/4.0/).

\section{Introduction}

Lignocellulosic biomass is the most abundant ( 1.3 billion tons) biomaterial on earth. Hydrolysis of lignocellulose to various reducing sugars has high economic importance in producing products such as bioethanol, biogases, etc. Lignocellulosic biomass consists of highstrength interconnected lignin, cellulose, and hemicellulose units. The presence of lignin leads to the dissolution of lignocellulosic biomass, and thus, hydrolysis of cellulose and hemicellulose in lignocellulosic biomass structure inhibits. Pretreatment using physical, chemical, physicochemical, and biological methods, lignin is removed with processes, and lignocellulosic biomaterials are made suitable for enzymatic hydrolysis. Cellulose, the largest component of lignocellulosic biomass, contains D-anhydroglucopyranose units. It is a linear polymer formed by combining with $\beta$-1,4-glycosidic bonds [1-4].

Cellulase enzymes are involved in the hydrolysis of cellulose. These; exoglucanase (CBH (cellobiohydrolase), EC 3.2.1.91), endoglucanase (EG, EC 3.2.1.4) and B-glucosidase (3.2.1.21). $\mathrm{CBHs}$ are effective on the crystalline region in the structure of cellulose and reduce disaccharide ( $\beta$-cellobiose) units. CBHs break non-reducing ends of cellulose. EGs are effective in the amorphous region of cellulose. They can also hydrolyze substituted celluloses such as carboxymethylcellulose (CMC) and hydroxy methylcellulose (HMC). $\beta$-glucosidases 
are responsible for the conversion of cellobiose units and other soluble oligosaccharides to glucose. There is synergy between enzymes for efficient hydrolysis of cellulose[5-9].

Cellulases are produced by bacteria and fungi. However, most enzyme companies (Novozymes, Genencor, Iogen etc.) commercial cellulase derived from fungi Trichoderma and Aspergillus strain them (Dyadic's Chrysosporium lucknownse). Although many cellulases producer of bacteria and fungi is found, it is still needed to investigate new cellulase producing microorganisms[10-13].

The aim of this study is to produce EG enzyme by using liquid culture technique from a local thermophilic fungus Aspergillus fumigatus HBF356, to purify EG enzyme produced by the precipitation of ammonium sulfate, gel filtration, and ion-exchange chromatography from the medium, to determine optimum $\mathrm{pH}$ and temperature for biochemical characterization of the purified enzyme. In addition, to evaluate the effect of gentamicin sulfate and enrofloxacin antibiotics used in animal diseases on the activity of the EG enzyme.

\section{Materials and Methods}

\subsection{Strains, medium, and culture conditions.}

A total of 31 thermophilic fungi were isolated from the soil and identified by Prof. Dr. Haci Halil Biyik (kindly gifted)[14]. The fungi were grown on the potato dextrose agar (PDA) plate containing $0.1 \%(\mathrm{w} / \mathrm{v})$ carboxymethylcellulose $(\mathrm{CMC})$ at $50{ }^{\circ} \mathrm{C}$ and screened for the cellulolytic activity. The fungi harboring endoglucanase activity showed a clear zone around the colony on the plate after staining with $1 \%(\mathrm{w} / \mathrm{v})$ Congo red. The enzyme production was performed in liquid medium containing $\left(\mathrm{CoCl}_{2}\right)(0.002 \mathrm{~g} / \mathrm{L}),\left(\mathrm{ZnSO}_{4}\right) \quad(0.0014 \mathrm{~g} / \mathrm{L})$, $\left(\mathrm{MnSO}_{4} .7 \mathrm{H}_{2} \mathrm{O}\right)(0.0015 \mathrm{~g} / \mathrm{L}),\left(\mathrm{FeSO}_{4}\right)(0.005 \mathrm{~g} / \mathrm{L}),\left(\mathrm{CaCl}_{2}\right)(0.3 \mathrm{~g} / \mathrm{L}),\left(\mathrm{MgSO}_{4}\right)(014 \mathrm{~g} / \mathrm{L})$, (urea) $(0.45 \mathrm{~g} / \mathrm{L}),\left(\left(\mathrm{NH}_{4}\right)_{2} \mathrm{SO}_{4}\right)(0.045 \mathrm{~g} / \mathrm{L}),\left(\mathrm{KH}_{2} \mathrm{PO}_{4}\right)(2 \mathrm{~g} / \mathrm{L})$, and $(\mathrm{CMC})(5 \mathrm{~g} / \mathrm{L})$ in water [15]. The $\mathrm{pH}$ of the medium was arranged to 5.0 and then autoclaved at $121^{\circ} \mathrm{C}$ for $15 \mathrm{~min}$. The medium was inoculated with Aspergillus fumigatus and incubated at $35^{\circ} \mathrm{C}$ for 5 days. At the end of the incubation, the culture was centrifuged at $8000 \mathrm{rpm}$ for 10 minutes. The supernatant was stored at $4{ }^{\circ} \mathrm{C}$ for further studies.

\subsection{Identification of fungi.}

For identification, ITS (The Internal Transcribed Spacer) gene regions were used for PCR. After the gene sequences were obtained, sequence analysis was performed using the BIOEDIT program. Molecular identification has been made by comparing the obtained results with the gene bank [16]. It was determined that the fungi obtained due to molecular characterization belong to Aspergillus, Penicillium, Fusarium, Rhizopus species. Organisms showing best growth at $40{ }^{\circ} \mathrm{C}$ or $50{ }^{\circ} \mathrm{C}$ were classified as thermotolerant and thermophilic, respectively.

\subsection{Activity determination.}

The activity of endoglucanase was detected by quantification of reducing the sugar by DNS method [17]. Briefly, $2.8 \mathrm{~mL}$ of $0.05 \mathrm{M}$ sodium citrate buffer ( $\mathrm{pH} 4.0$ ) containing $1 \%$ $(\mathrm{w} / \mathrm{v}) \mathrm{CMC}$ and $0.05 \mathrm{~mL}$ crude enzyme solution were transferred to the test tube, which was incubated at $50{ }^{\circ} \mathrm{C}$ for 30 minutes. At the end of the incubation, $3 \mathrm{~mL}$ of DNS was added to the test tube. All tubes were boiled in a boiling water bath for 15 minutes (enzyme, blank and 
standard tubes). Tubes taken from the hot water bath were directly transferred to the cold water bath. Then, the absorbance of tubes was read at $540 \mathrm{~nm}$.

\subsection{Protein assay.}

Bradford's (1976) method was used for protein quantification. BSA (Bovine Serum Albumin) was used as a standard [18].

\subsection{Purification of endoglucanase.}

The supernatant obtained after centrifugation of the culture was used for the purification of endoglucanase. Firstly, ammonium sulfate precipitation was performed in the supernatant. In the first experiment, starting from $0-20 \%$ saturation, precipitation was made with an increase of $20 \%$ up to $100 \%$ saturation. It is aimed to use this range in the next studies by determining the saturation range where the enzyme activity is the highest from the solutions obtained after the precipitates are dissolved in the least amount of suitable buffer. The highest enzyme activity was determined as 50-80\%, and this range was used in subsequent studies. The sample obtained after ammonium sulfate precipitation was dialyzed with 3 liters of the buffer. The dialysis sample was applied to gel filtration chromatography (Sephadex G-100) and then DEAE Sephadex (A-50 Biorad laboratories) anion exchange chromatography [19]. Active eluents were collected and kept at $4{ }^{\circ} \mathrm{C}$ for subsequent studies. Also, the obtained endoglucanase preparation was applied on SDS-PAGE to confirm the purity of the enzyme.

\subsection{Determination of optimum $\mathrm{pH}$ and temperature.}

In this study, the enzyme was incubated in different buffers between $\mathrm{pH} 4.0$ and 9.0 in order to determine the effect of $\mathrm{pH}$ on enzyme activity and to determine the $\mathrm{pH}$ at which optimum activity is obtained, and the relative activity was determined by the activity determination method. $50 \mathrm{mM}$ citrate $(\mathrm{pH} 4.0-6.0)$ and $50 \mathrm{mM}$ phosphate (pH 6.0-9.0) buffers were used in the study.

To determine optimum temperature, enzyme activity was evaluated between $30-70^{\circ} \mathrm{C}$ in order to examine the effect of temperature on the activity of the endoglucanase enzyme.

\subsection{Thermal stability of endoglucanase.}

Purified endoglucanase was incubated at $50{ }^{\circ} \mathrm{C}$ to determine the thermal stability of the purified endoglucanase in the study. According to the standard activity method, endoglucanase enzyme activity was determined, taken from the enzyme solution at different time intervals. The decrease in enzyme activity was shown by the relative activity calculated by comparison with the initial enzyme activity.

\subsection{Effect of drugs on endoglucanase enzyme activity.}

The effect of the veterinary drugs gentamicin and enrofloxacin on endoglucanase; It was determined using different concentrations of these drugs. The concentrations used for the drug gentamicin were $0,1.35,5.41,6.70,8.46,13.54,20.31 \mathrm{mM}$, respectively, while the studied concentrations of the drug enrofloxacin were $0,0.884,1.768,3.536,7.072,8.84 \mathrm{mM}$. 


\section{Results and Discussion}

\subsection{Identification of fungi.}

The endoglucanase production capacity of a large number of fungi isolated from soil were tested on agar. Molecular characterization of the fungi used was carried out as described in Section 2.2. A phylogenetic tree of fungi was created using the data obtained as a result of molecular characterization (Figure 1). It was determined that the fungi obtained as a result of molecular characterization belong to Aspergillus, Penicillium, Fusarium, Rhizopus species. Endoglucanase producers among these fungi were determined by agar staining method Fungi on PDA containing $0.1 \% \mathrm{CMC}$ were grown at $40{ }^{\circ} \mathrm{C}$ for 24 hours and then dyed with $1 \%$ Congo red and then washed with $1 \mathrm{M} \mathrm{NaCl}$ on the surface of the Petri dish. Fungi that formed a light yellow zone on the petri dish were considered to be positive. In this study, the largest zone formation was obtained in Aspergillus fumigatus HBF356 (data not shown), which was used as an endoglucanase producer in this study.

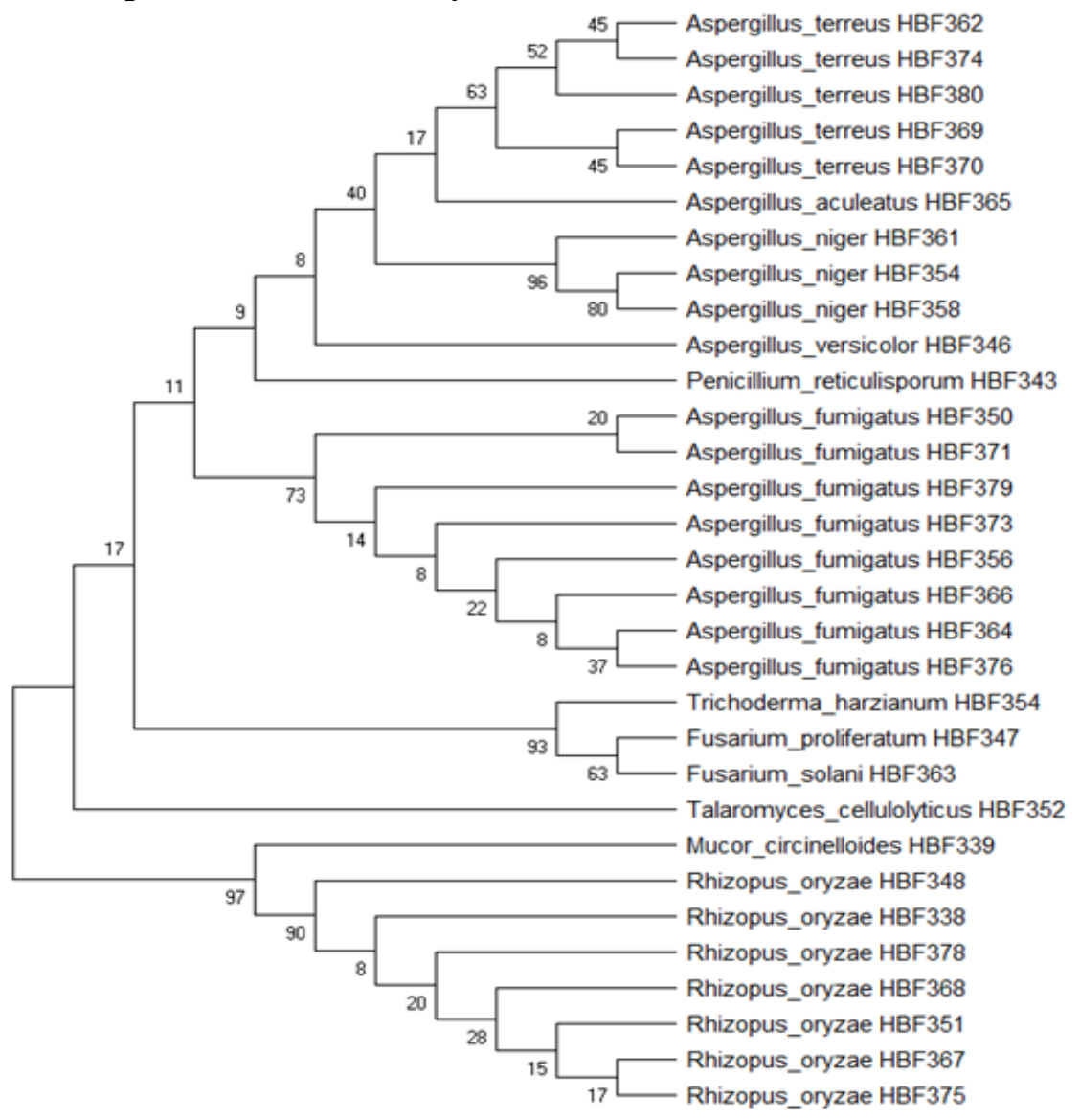

Figure 1. Phylogenetic analysis of the fungi.

\subsection{Production and purification of endoglucanase.}

Production of endoglucanase from Aspergillus fumigatus HBF356 was performed in a liquid medium containing $\mathrm{CMC}$ as a carbon source. It was determined that the endoglucanase activity reached the highest level after 5 days of incubation at $35^{\circ} \mathrm{C}$. At the end of the 5 th day, the culture medium was centrifuged at $8000 \mathrm{rpm}$ for 30 minutes. The supernatant obtained by centrifugation was stored at $4{ }^{\circ} \mathrm{C}$ for use in the next steps as the enzyme source.

The purification steps for the endoglucanase obtained from Aspergillus fumigatus HBF356 were as follows: 
1. Ammonium sulfate precipitation was applied at 50-80\% saturation to the supernatant.

2. The precipitate obtained after ammonium sulfate precipitation was dissolved in the minimum amount of $50 \mathrm{mM} \mathrm{pH} 4.0$ citrate buffer.

3 . The precipitate was dialyzed to remove the salt.

4. The desalted enzyme solution was loaded on gel filtration chromatography (Sephadex G-100).

5. Absorbances of the eluents obtained from the column were read at $280 \mathrm{~nm}$, and then the endoglucanase activity was examined in the eluents.

6 . The highest activity eluents were combined, and the next purification step proceeded.

7. The mixture obtained was applied to ion-exchange chromatography (DEAESephadex A-50), and gradient separation was performed with $1 \mathrm{M} \mathrm{NaCl}$.

8. Eluents with endoglucanase activity were combined. The purification coefficient was calculated by determining the activity and protein in this mixture obtained. Thus, the effectiveness of the methods used was determined.

The specific activity of purified endoglucanase was $0.0043 \mathrm{EU} \mathrm{mg}^{-1}$ and a yield of 1.26 $\%$. The purification procedure is summarized in Table 1 .

Table 1. Summary of the purification of endoglucanase from Aspergillus fumigatus HBF356.

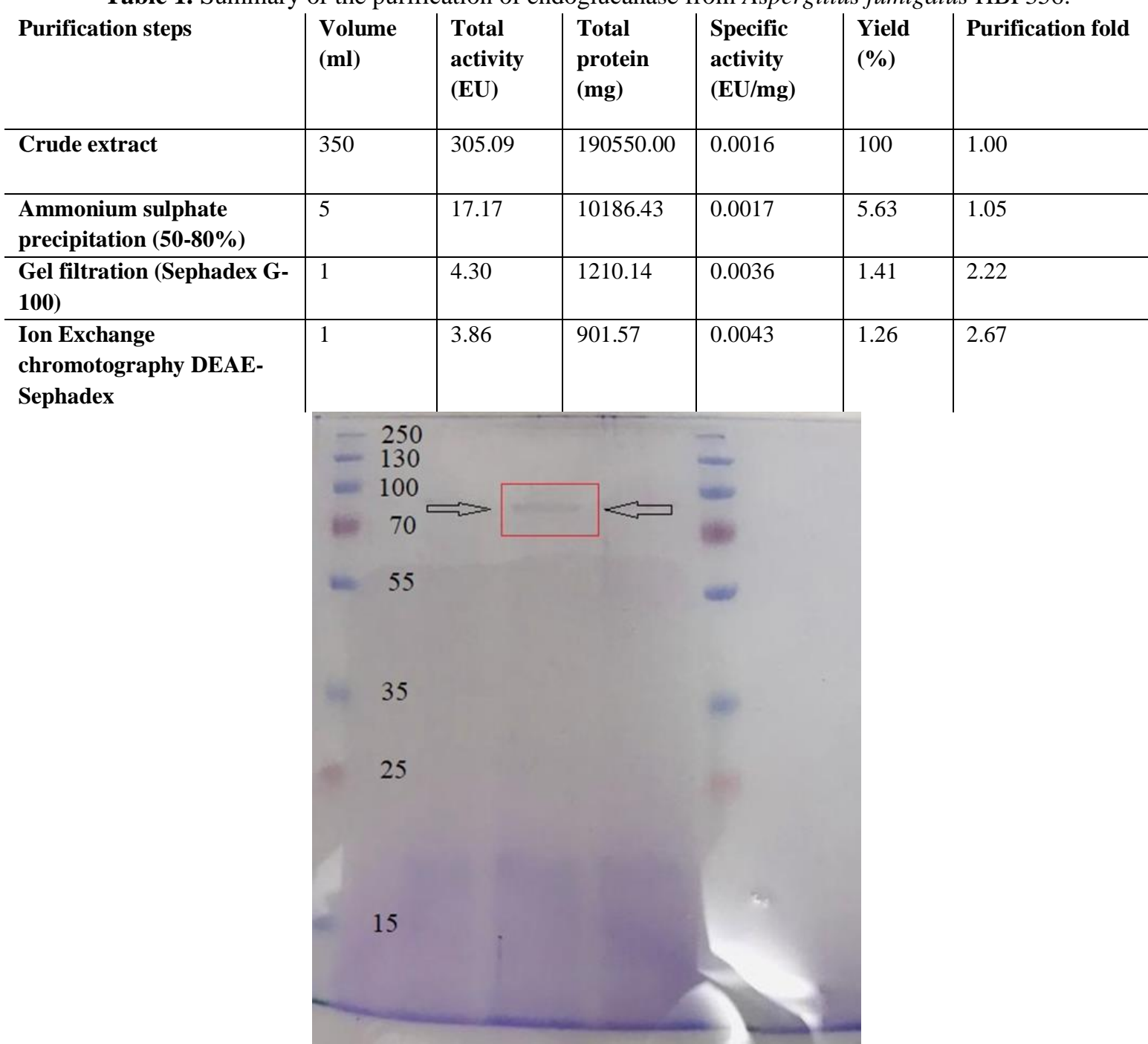

Figure 2. SDS-PAGE of the purified endoglucanase from A. niger Aspergillus fumigatus HBF356 by ammonium sulfate precipitation, Sephadex G-100, and DEAE-Sephadex; lane 1: Marker; lane 2: endoglucanase preparation. 
In this study, SDS-PAGE was performed for purity control and molecular weight determination of endoglucanase purified from Aspergillus fumigatus HBF356. The SDS-PAGE image of the endoglucanase obtained in this study is given in Figure 2. A single band of endoglucanase was obtained on the gel. The molecular weight of this band is determined to be $\sim 95 \mathrm{kDa}$.

Hasper et al. [20] was isolated and identified the EglC gene from Aspergillus niger. The molecular weight of the endoglucanase enzyme expressed by this gene was determined to be approximately $90.5 \mathrm{kDa}$. Based on this, it can be said that the endoglucanase purified from Aspergillus fumigatus HBF356 in this study belongs to the endoglucanase expressed by the EglC gene. Nazir et al. [21] reported purification of endoglucanase from Aspergillus terreus with $80 \mathrm{kDa}$.

\subsection{Optimum $\mathrm{pH}$ and temperature.}

In order to determine the effect of $\mathrm{pH}$ on enzyme activity, activity was determined as specified in Section 2.3. The $\mathrm{pH}$ of the incubation buffer used in the activity method was changed between 3.0 and 8.0. In our study, $50 \mathrm{mM}$ citrate (pH 3.0-6.0) and $50 \mathrm{mM}$ phosphate (7.0-8.0) buffers were used. From the graph drawn between the relative activity of the enzyme and $\mathrm{pH}$, the optimum $\mathrm{pH}$ value of the enzyme was determined (Figure 3). Accordingly, it was determined that the purified endoglucanase from Aspergillus fumigatus HBF356 showed optimum activity in $50 \mathrm{mM} \mathrm{pH} 4.0$ citrate buffer. As a result of searching on Brenda (https://www.brenda-enzymes.org ), it was determined that the optimum $\mathrm{pH}$ value of endoglucanases obtained from Aspergillus species was between 3.8-4.0. Previously, endoglucanase from Aspergillus niger [22] and Aspergillus terreus [21] similarly showed optimum activity at $\mathrm{pH}$ 4.0. In this study, the endoglucanase purified from Aspergillus fumigatus HBF356 has a similar optimum $\mathrm{pH}$.

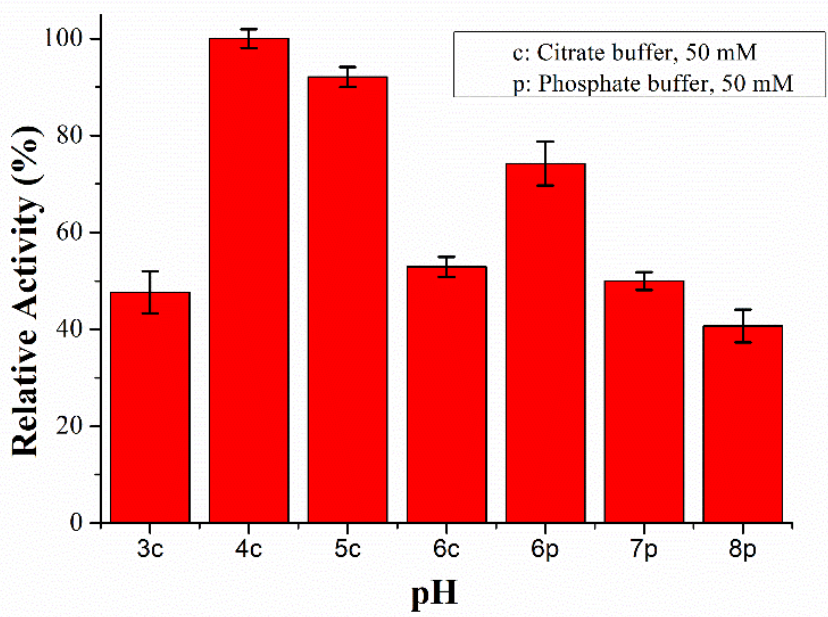

Figure 3. The effect of $\mathrm{pH}$ on the purified endoglucanase from Aspergillus fumigatus HBF356.

Temperature is an important factor affecting both the speed and stability of enzymes. The speed of the enzymatic reaction increases with the temperature, but when it rises above a certain value, there is a sudden decrease in its activity. This is because enzymes with protein structures denature at high temperatures. Each enzyme has a certain temperature value that shows maximum activity, and it is expressed as the optimum temperature value.

In this study, activity determination was made as specified in Section 2.3 to examine the effect of temperature on enzyme activity. While determining the activity, the enzyme 
activity was determined by changing the incubation temperature between $30-80{ }^{\circ} \mathrm{C}$. The optimum temperature value of the enzyme was determined from the graph drawn against the temperature values by calculating the relative activity values with the obtained activity values (Figure 4). Accordingly, it was determined that the enzyme has an optimum temperature value at $60{ }^{\circ} \mathrm{C}$. In addition, it can be said from this graph that the activity of the enzyme is low at low temperatures, the activity value increases at $50^{\circ} \mathrm{C}$ and above, and it is quite stable between 50-80 ${ }^{\circ} \mathrm{C}$. In previous studies, it was reported that Aspergillus sp. endoglucanases showed optimum activity at $50{ }^{\circ} \mathrm{C}[14,21,23]$. Also, it was shown that endoglucanase from thermophilic Thermobifida fusca strain UPMC 901 had an optimum temperature at $60{ }^{\circ} \mathrm{C}$ [24].

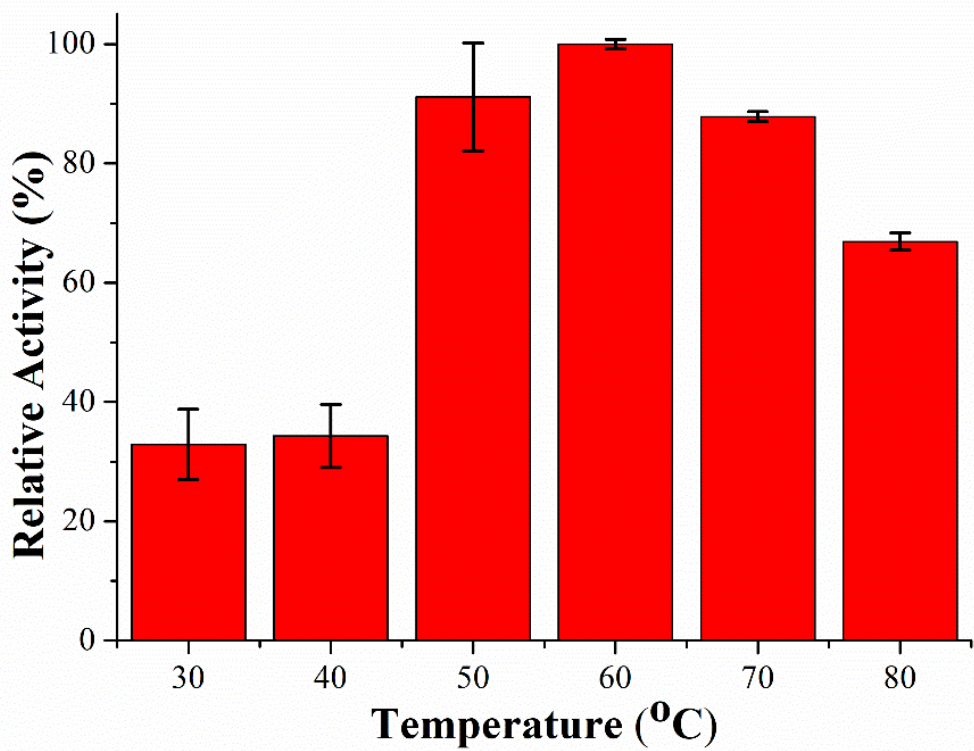

Figure 4. The effect of temperature on the purified endoglucanase from Aspergillus fumigatus HBF356.

\subsection{Thermal stability.}

In order to determine the thermal stability of the purified endoglucanase, the enzyme was incubated at $50{ }^{\circ} \mathrm{C}, \mathrm{pH} 4.0(50 \mathrm{mM}$ citrate buffer). The residual activity of the enzyme was determined by taking samples from this enzyme solution at certain intervals between 0 240 hours. The thermal stability of the endoglucanase was determined by plotting the relative activity values compared to the initial enzyme activity against the incubation time (Figure 5). It was determined that $75.8 \%$ of the enzyme's activity was maintained at the incubation of 240 hours at $50^{\circ} \mathrm{C}, \mathrm{pH} 4.0$ (50 mM citrate buffer). The enzyme was also sustained almost all of its initial activity after $24 \mathrm{~h}$. With this study, it has been shown that the enzyme is thermostable and that it can be used in high temperature and acidic $\mathrm{pH}$ operating ranges. This is important for the biotechnology industry, such as non-ionic surfactant-assisted acidic deinking of old newsprint and old magazines [21, 25].

Endoglucanase enzyme obtained from A. terreus DSM 826 showed no activity loss at $50{ }^{\circ} \mathrm{C}$ for 1 hour [26]. Endoglucanase enzyme obtained from A. terreus M11 lost $60 \%$ of its activity after 1-hour incubation at $70{ }^{\circ} \mathrm{C}$ [23]. Endoglucanase purified from Aspergillus niger VTCC-F021 preserved $60 \%$ of its activity after 8 hours of incubation at $50{ }^{\circ} \mathrm{C}$ [27]. When compared with these studies, it can be said that endoglucanase purified from Aspergillus fumigatus HBF356 has a very high thermostability[28]. 


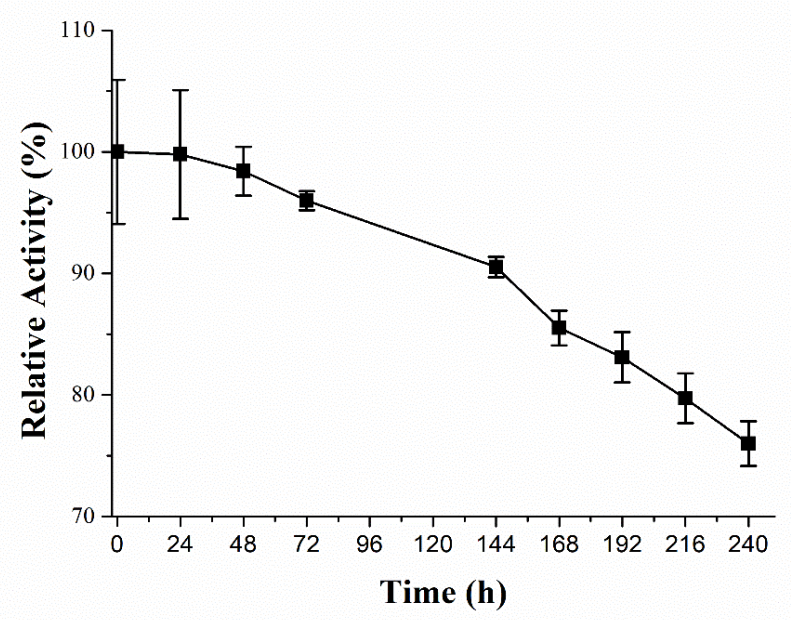

Figure 5. Thermal stability of the purified endoglucanase from Aspergillus fumigatus $\mathrm{HBF} 356$ at $50{ }^{\circ} \mathrm{C}$, $\mathrm{pH} 4.0$.

\subsection{Effect of drugs on endoglucanase activity.}

As stated in Section 2.8, the effect of different concentrations of gentamicin and enrofloxacin drugs on endoglucanase activity was investigated. These two drugs can be used as antibiotics in animals such as cats, dogs, and sheep to stop bacterial growth [29].

In order to determine the effect of gentamicin sulfate on endoglucanase activity, it has been studied in the concentration range of 0-20.31 mM. Results are shown in Figure 6. As a result of the study, it was determined that $42 \%$ of the enzyme's activity remained at $20.31 \mathrm{mM}$ gentamicin sulfate concentration.

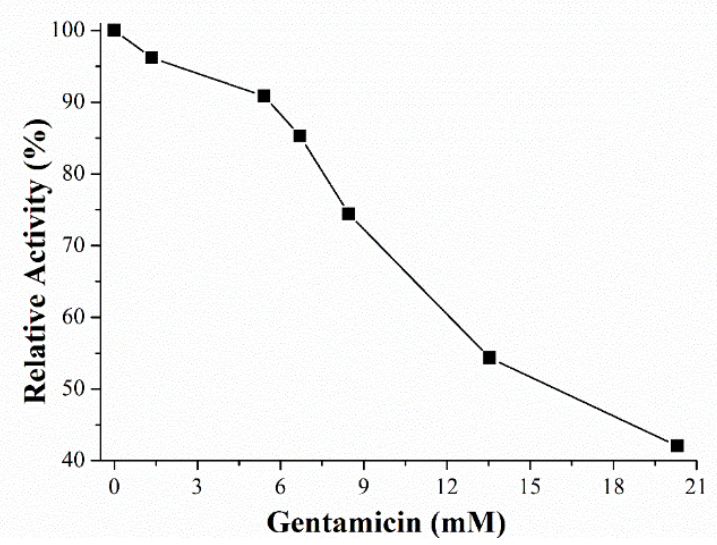

Figure 6. The effect of gentamicin on the purified endoglucanase from Aspergillus fumigatus HBF356.

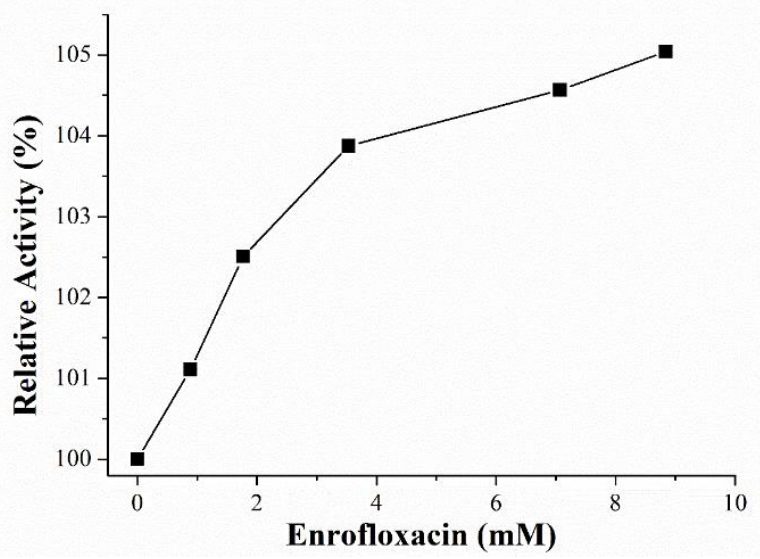

Figure 7. The effect of enrofloxacin on the purified endoglucanase from Aspergillus fumigatus HBF356. 
In order to determine the effect of the enrofloxacin on the endoglucanase activity, a concentration range of 0-8.84 $\mathrm{mM}$ was studied. As seen in Figure 7, enrofloxacin activated the endoglucanase activity. It maintains $105 \%$ of the enzyme's activity at a concentration of 8.84 mM enrofloxacin.

\section{Conclusions}

As a result, in this study, the endoglucanase enzyme from Aspergillus fumigatus HBF356 was purified using ammonium sulfate precipitation, gel filtration chromatography, and ionexchange chromatography. The molecular weight of the pure enzyme was determined as 95 $\mathrm{kDa}$. The optimum $\mathrm{pH}$ of the obtained enzyme was determined as 4.0 and the optimum temperature as $60^{\circ} \mathrm{C}$. It has been observed that the enzyme has a very high thermostability and preserves $75.8 \%$ of its activity after 240 hours of incubation at $50{ }^{\circ} \mathrm{C}$. Therefore, the enzyme is highly thermostable. Because of these properties, it can be said that the enzyme has potential for industrial use. At the same time, the activity of veterinary drugs on the activity of the enzyme was investigated, and it was determined that the enzyme was inhibited by gentamicin sulfate and that the activity was with enrofloxacin. Thus, information has been provided on how this enzyme interacts with animal drugs as a feed additive.

\section{Funding}

This research received no external funding.

\section{Acknowledgments}

The authors would like to thank Prof. Dr. Hac1 Halil BIYIK and his group for microorganisms.

\section{Conflicts of Interest}

The authors declare no conflict of interest.

\section{References}

1. Berto, G.L.; Mattos, B.D.; Rojas, O.J.; Arantes, V. Single-Step Fiber Pretreatment with Monocomponent Endoglucanase: Defibrillation Energy and Cellulose Nanofibril Quality. ACS Sustainable Chemistry \& Engineering 2021, 9, 2260-2270, https://doi.org/10.1021/acssuschemeng.0c08162.

2. Liu, X.; Jiang, Y.; Wang, L.; Song, X.; Qin, C.; Wang, S. Tuning of size and properties of cellulose nanofibers isolated from sugarcane bagasse by endoglucanase-assisted mechanical grinding. Industrial Crops and Products 2020, 146, 112201, https://doi.org/10.1016/j.indcrop.2020.112201.

3. Xu, Y.; Yang, S.; Zhao, P.; Wu, M.; X. Song, A.J. Ragauskas. Effect of endoglucanase and high-pressure homogenization post-treatments on mechanically grinded cellulose nanofibrils and their film performance. Carbohydr Polym 2021, 253, 117253, https://doi.org/10.1016/j.carbpol.2020.117253.

4. Manna, B., Ghosh, A.. Structure and dynamics of ionic liquid tolerant hyperthermophilic endoglucanase Cel12A from Rhodothermus marinus. RSC Advances 2020, 10, 7933-7947, https://doi.org/10.1039/c9ra09612d.

5. Zou, G.; Bao, D.; Wang, Y.; Zhou, S.; Xiao, M.; Yang, Z.; Wang, Y., Zhou, Z. Alleviating product inhibition of Trichoderma reesei cellulase complex with a product-activated mushroom endoglucanase. Bioresour Technol 2021, 319, 124119, https://doi.org/10.1016/j.biortech.2020.124119.

6. Zhang, P.; Cui, M.; Huang, R.; Qi, W.; Thielemans, W.; He, Z.; Su, R.. Enhanced enzymatic hydrolysis of cellulose by endoglucanase via expansin pretreatment and the addition of zinc ions. Bioresour Technol 2021, 333, 125139, https://doi.org/10.1016/j.biortech.2021.125139. 
7. Lv, K.; Shao, W.; Pedroso, M.M.; Peng, J.; Wu, B.; Li, J.; He, B.; Schenk, G. Enhancing the catalytic activity of a GH5 processive endoglucanase from Bacillus subtilis BS-5 by site-directed mutagenesis. Int J Biol Macromol 2021, 168, 442-452, https://doi.org/10.1016/j.ijbiomac.2020.12.060.

8. Aich, S.; Datta, S. Engineering of a highly thermostable endoglucanase from the GH7 family of Bipolaris sorokiniana for higher catalytic efficiency. Appl Microbiol Biotechnol 2020, 104, 3935-3945, https://doi.org/10.1007/s00253-020-10515-0.

9. Sar, A.; Pal, S.; Islam, S.; Mukherjee, P.; Dam, B. An Alkali-Halostable Endoglucanase Produced Constitutively by a Bacterium Isolated from Sambhar Lake in India with Biotechnological Potential. Proceedings of the National Academy of Sciences, India Section B: Biological Sciences 2021, 91, 319-326, https://doi.org/10.1007/s40011-021-01230-5.

10. Ibrahim, A.M.; Hamouda, R.A.; El-Naggar, N.E.; Al-Shakankery, F.M. Bioprocess development for enhanced endoglucanase production by newly isolated bacteria, purification, characterization and in-vitro efficacy as anti-biofilm of Pseudomonas aeruginosa. Sci Rep 2021, 11, 9754, https://doi.org/10.1038/s41598021-87901-9.

11. Kuhad, R.C.; Gupta, R.; Singh, A. Microbial cellulases and their industrial applications. Enzyme Res 2011, 2011, 280696, https://doi.org/10.4061/2011/280696.

12. Dotsenko, A.S.; Rozhkova, A.M.; Zorov, I.N.; Sinitsyn, A.P. Protein surface engineering of endoglucanase Penicillium verruculosum for improvement in thermostability and stability in the presence of 1-butyl-3methylimidazolium chloride ionic liquid. Bioresour Technol 2020, 296, 122370, https://doi.org/10.1016/j.biortech.2019.122370.

13. Chavez-Guerrero, L.; Silva-Mendoza, J.; Toxqui-Teran, A.; Vega-Becerra, O.E.; Salinas-Montelongo, J.A.; Perez-Camacho, O. Direct observation of endoglucanase fibrillation and rapid thickness identification of cellulose nanoplatelets using constructive interference. Carbohydr Polym 2021, 254, 117463, https://doi.org/10.1016/j.carbpol.2020.117463.

14. Tao, Y.M.; Zhu, X.Z.; Huang, J.Z.; Ma, S.J.; Wu, X.B.; Long, M.N.; Chen, Q.X. Purification and properties of endoglucanase from a sugar cane bagasse hydrolyzing strain, Aspergillus glaucus XC9. J Agric Food Chem 2010, 58, 6126-30, https://doi.org/10.1021/jf1003896.

15. Mawadza, C.; R. Hatti-Kaul; R. Zvauya, B. Mattiasson. Purification and characterization of cellulases produced by two Bacillus strains. Journal of Biotechnology 2000, 83, 177-187.

16. Yazici, S.O.; Sahin, S.; Biyik, H.H.; Geroglu, Y.; Ozmen, I. Optimization of fermentation parameters for high-activity inulinase production and purification from Rhizopus oryzae by Plackett-Burman and BoxBehnken. J Food Sci Technol 2021, 58, 739-751, https://doi.org/10.1007/s13197-020-04591-3.

17. Ghose, T.K. Continuous enzymatic saccharification of cellulose with culture filtrates oftrichoderma viride QM 6a. Continuous enzymatic saccharification of cellulose with culture filtrates oftrichoderma viride QM 6a. Biotechnology and Bioengineering, 1969, 11, 239-261.

18. Bradford, M.M. A rapid and sensitive method for the quantitation of microgram quantities of protein utilizing the principle of protein-dye binding. Analytical Biochemistry 1976, 72 248-254.

19. Kotchoni, S.O.; Gachomo, E.W.; Omafuvbe, B.O.; Shonukan, O.O. Purification and Biochemical Characterization of Carboxymethyl Cellulase (CMCase) from a Catabolite Repression Insensitive Mutant of Bacillus pumilus. International Journal of Agriculture and Biology 2006, 8.

20. Hasper, A.A.; Dekkers, E.; van Mil, M.; van de Vondervoort, P.J.; de Graaff, L.H. EglC, a new endoglucanase from Aspergillus niger with major activity towards xyloglucan. Appl Environ Microbiol 2002, 68, 1556-60, https://doi.org/10.1128/aem.68.4.1556-1560.2002.

21. Nazir, A.; Soni, R.; Saini, H.S.; Manhas, R.K.; Chadha, B.S. Purification and characterization of an endoglucanase from Aspergillus terreus highly active against barley $\beta$-glucan and xyloglucan. World Journal of Microbiology and Biotechnology 2009, 25, 1189-1197, https://doi.org/10.1007/s11274-009-0001-y.

22. Sulyman, A.O.; Igunnu, A.; Malomo, S.O. Isolation, purification and characterization of cellulase produced by Aspergillus niger cultured on Arachis hypogaea shells. Heliyon 2020, 6, e05668, https://doi.org/10.1016/j.heliyon.2020.e05668.

23. Elshafei, A.M.; Hassan, M.M.; Haroun, B.M.; Abdel-Fatah, O.M.; Atta, H.M., Othman, A.M. Purification and properties of an endoglucanase of Aspergillus terreus DSM 826. J Basic Microbiol 2009, 49, 426-32, https://doi.org/10.1002/jobm.200800227. 
24. Zainudin, M.H.M.; Mustapha, N.A.; Hassan, M.A.; Bahrin, E.K.; Tokura, M.; Yasueda, H.; Y. Shirai. A highly thermostable crude endoglucanase produced by a newly isolated Thermobifida fusca strain UPMC 901. Sci Rep 2019, 9, 13526, https://doi.org/10.1038/s41598-019-50126-y.

25. Han, C.; Liu, Y.; Liu, M.; Wang, S.; Q. Wang. Improving the thermostability of a thermostable endoglucanase from Chaetomium thermophilum by engineering the conserved noncatalytic residue and $\mathrm{N}$-glycosylation site. Int J Biol Macromol 2020, 164, 3361-3368, https://doi.org/:10.1016/j.ijbiomac.2020.08.225.

26. Gao, J.; Weng, H.; Xi, Y.; Zhu, D.; Han, S. Purification and characterization of a novel endo-beta-1,4glucanase from the thermoacidophilic Aspergillus terreus. Biotechnol Lett 2008, 30, 323-7, https://doi.org/10.1007/s10529-007-9536-x.

27. Pham, T.H.; Quyen, D.T.; Nghiem, N.M. Purification and properties of an endoglucanase from Aspergillus niger VTCC-F021. Turk J Biol 2012, 36, 694-701, https://doi.org/10.3906/biy-1202-30.

28. Lv, K.; Yu, Z.; Pedroso, M.M.; Wu, B.; Gao, Z.; He, B.; Schenk, G. Metal Affinity Immobilization of the Processive Endoglucanase EG5C-1 from Bacillus subtilis on a Recyclable pH-Responsive Polymer. ACS Sustainable Chemistry \& Engineering 2021, 9, 7948-7959, https://doi.org/10.1021/acssuschemeng.1c02215.

29. Raza, A.; Bashir, S.; Pothula, R.; Abdelgaffar, H.; Tabassum, R.; Anwar, M.I.; Awais, M.M.; Akhtar, M.; Jurat-Fuentes, J.L. Expression and functional characterization in yeast of an endoglucanase from Bacillus sonorensis BD92 and its impact as feed additive in commercial broilers. Int J Biol Macromol 2021, 176, 364375, https://doi.org/10.1016/j.ijbiomac.2021.02.022. 